household names - G.G. Coulton, Dom David Knowles, Sir Stephen Runciman, Sir John Clapham, Eileen Power and many more.

Altogether, the decades between the two World Wars may perhaps be seen as the greatest years in all of CUP's existence. Onto financial stability and imaginative publishing were grafted the typographical influence of Stanley Morison, making the Press a leader in Britain and the world in the combination of style with clarity in typographical design. There are many reasons for reading Black's book and among them is a series of brief but effective character sketches - of Morison, for example, quite obviously a most eccentric man despite (or because of) being a typographical genius; or of someone called Nobbs who, according to Black, was "curmudgeonly until excited, when he became virtually impossible".

Throughout its history the Press has had difficulties - financial and political - but none so severe as the crisis of the late $1960 \mathrm{~s}$ and early 1970 s which threatened to take it under. The extent of the problem is made clear by Lord Todd, appointed as Chairman of the Syndics in 1971, in his autobiography $A$ Time to Remember (quoted by Black on p. 243):

Already on my first visit as Chairman...I was horrified: the Press was to all intents and purposes bankrupt, with a soaring overdraft and with sales and receipts dwindling.

Todd moved with remarkable speed and steered through the appointment of Geoffrey Cass who, as Chief Executive, must be credited with the reorganization that has made CUP as efficient and, I suspect, as profitable as it is today. (One can only suspect; while Black is by and large good on quoting figures, numbers of employees and so on, he is brief to the point of evasiveness on the current turnover and profit of the Press.)

Cass did many things that needed doing. Among them was the enforcement of the policy that current book prices had to reflect replacement costs, not original costs, a point it has taken far too many publishers far too long to realize during the past decades. Indeed, of the many constituencies in the potential audience of this book, the oddest, I suspect, must be the world of accountants. The master-stroke, however, came from a different direction. By brilliant research in the university archives and sophisticated presentation of his arguments, Cass managed to persuade the Inland Revenue that the Press should become a charity which would be exempt from payment of corporation tax. His 1975 submission to the District Inspector of Taxes consisted of some 60 typewritten pages, one of which contained the sentence "Our formal submission, when completed in the Spring, is likely to be several hundred times bigger...". Clearly Mr Cass is not a man to be trifled with. He succeeded in his aim when the Inland Revenue agreed on 9

\section{Developments in holography}

\section{Brian J. Thompson}

Optical Holography: Principles,

Techniques and Applications.

By P. Hariharan.

Cambridge University Press: 1984. Pp.

319. £35, $\$ 69.50$.

IN HIS preface, Dr Hariharan states: "My aim in writing this book is to present a selfcontained treatment of the principles, techniques and applications of optical holography, with particular emphasis on recent developments". He has succeeded admirably in that endeavour. It was time for a new, authoritative text on holography, to provide a succinct but readable introduction to the principles and current methodology of optical holography, and up-to-date coverage of applications.

The book contains 15 chapters and five short appendices. The first three chapters are concerned with the fundamentals, the first giving some historical perspective, the next two being accounts of the basic methods of hologram formation (in-line, offaxis, Fourier transform, Fraunhofer, and image) and of image formation from the hologram. The various types of holographic recordings (thin, volume transmission and volume reflection) are described in some detail in a separate chapter.

Three further chapters deal with many of the important practical aspects of the art and science of holography, including light sources and optical systems, parameters of recording media and practical recording media. Various useful chemical formulae and processing conditions are given for monobath developers, tanning bleach, reversal bleach, dichromated gelatin and so on.

Separate chapters are devoted to holograms for displays, colour holography, computer-generated holograms, information storage and processing and holographic interferometry. Special tech-

November 1976 that CUP was indeed tax exempt. The so-called older university, and younger university press over at Oxford, watched elegantly from the sidelines and subsequently procured the same exemption.

The extent of Cass's success and the present health of CUP can be judged from the current scale of the Press's activities. Nineteen eighty-four, it is estimated, will have seen from the publisher of Newton and Darwin, Dryden and Milton, some 900 new publications with projected sales of eight million units.

This is an altogether admirable book, hugely enjoyable and informative. It is superbly produced - the broken letter in the word "editorial"' (p. 286) apart - and niques - including polarization recording, hologram copying and holography with incoherent light - are discussed as a group. (I confess I still have semantic difficulty with the phrase "holography with incoherent light", or worse yet "incoherent holography"!)

Imaging applications of holography are covered, among them microscopy, particle size analysis, imaging through moving scatterers and distorting media, correction of aberrated wavefronts, high-resolution projection imaging, evanescent-wave holography and multiple imaging. Rather oddly, this chapter also contains sections on holographic optical elements including scanners and diffraction gratings.

Some readers will be disappointed by the brevity of one or two of the sections; for example, the discussion of holographic gratings takes a bare two-and-a-half pages, including two figures. However, to compensate, there are ample references in all sections, some 700 in all, about $10 \%$ of which are from 1980-1982; the author has indulged himself a little with the largest number (32) to his own work - at least twice as many as the nearest competitor! There is also a short bibliography, an author index and a very good subject index, although I was surprised that multiplex hologram, zone plate, zone lens and far-field hologram are not included.

Topics such as speckle, interference and coherence are dealt with briefly in the appendices. Coherence requirements are important but unfortunately the author repeatedly writes about the spatial coherence of the source when he means the spatial coherence of the field produced by the source.

Such small defects do not affect the overall value of the book. It will appeal to a wide audience, from those embarking on a serious study of holography to the established researcher who will use it as a reference text.

Brian J. Thompson is Professor of Optics in the College of Engineering and Applied Science and Provost at the University of Rochester, New York.

so indeed it should be. Black's prose is lucid and frequently witty, while the work as a whole is far less self-serving than most volumes of a similar nature. My only real disappointment is the absence of the present-day figures that really matter. If companies who do pay their taxes have to tell all, should not charitable institutions also be compelled to report fully - if only to reassure those of us who toil elsewhere in the vineyards of publishing that the two great university presses are not thereby gaining a massive commercial advantage.

T.G. Rosenthal is Joint Chairman and Joint Managing Director of André Deutsch Ltd, London. 